\title{
ЩОДО НЕОБХІДНОСТІ РОЗРОБЛЕННЯ ТА ВПРОВАДЖЕННЯ СИСТЕМИ ВІЙСЬКОВО-МЕДИЧНИХ СТАНДАРТІВ У ЗБРОЙНИХ СИЛАХ УКРАЇНИ
}

\author{
В.Г. Лівінський ${ }^{1}$ В.О. Жаховський ${ }^{1}$, О.М. Іванько ${ }^{1}$, В.М. Івчук ${ }^{1}$, О.М. Серебряков² \\ 1 Українська військово-медична академія, м. Київ, Україна \\ 2 Житомирський військовий госпіталь, м. Житомир, Украӥна
}

Вступ. Системне реформування у сфері національної безпеки та оборони в Україні висуває високі вимоги до медичного забезпечення ЗС України. Одним із ефективних механізмів впливу держави на якість надання медичної допомоги військовослужбовиям $\epsilon$ стандартизація медичного забезпечення, що спрямована на досягнення оптимального ступеня впорядкування в системі військової охорони здоров'я шляхом розроблення та впровадження норм, вимог, правил, технологій, робіт, послуг, що застосовуються в охороні здоров'я.

Мета. Обгрунтування необхідності розроблення системи військово-медичних стандартів та визначення порядку ї впровадження у систему медичного забезпечення Збройних Сил (ЗС) України.

Матеріали та методи. Використано законодавчі та нормативно-правові акти з питань охорони здоров'я, керівні документи щодо медичного забезпечення ЗС України, інформаційно-довідкові матеріали, монографії та наукові статті щодо опрацювання та провадження стандартів надання медичної допомоги, а також керівні документи з медичного забезпечення збройних сил держав-членів НАТО. Об'єкт дослідження - система медичного забезпечення ЗС України. Предмет дослідження - система військовомедичних стандартів у ЗС України. Методи дослідження: бібліографічний, аналітичний, системного підходу, узагальнення, прогностичний.

Результати. Вивчено та проаналізовано нормативно-правові акти, що визначають організацію та порядок медичного забезпечення ЗС України, необхідність впровадження військово-медичних стандартів у діяльність медичної служби, а також керівні документи з медичного забезпечення збройних сил державчленів НАТО. Проведено дослідження стану розроблення та впровадження системи військово-медичних стандартів у ЗС України та встановлено, що до цього часу робота щодо стандартизації медичного забезпечення ЗС України не набула системного характеру, розроблено лише окремі документи з питань стандартизації надання медичної допомоги, підготовки військовослужбовців з тактичної медицини та медичного постачання. Загальна система військово-медичних стандартів у ЗС України залишається нерозробленою та не впровадженою.

Висновки. Робота щодо розроблення та впровадження системи військово-медичних стандартів у медичне забезпечення ЗС України залишається незавершеною, а система військово-медичних стандартів нерозробленою, що викликає необхідність проведення науково-дослідної роботи із зазначеної проблеми.

Ключові слова: медичне забезпечення ЗС України, стандарти надання медичної допомоги, система військово-медичних стандартів.

Вступ. Кожний громадянин України має право на охорону здоров'я та надання йому якісної медичної допомоги - це право закріплене законом України «Основи законодавства України про охорону здоров'я». Медична допомога - діяльність професійно підготовлених медичних працівників, спрямована на профілактику, діагностику, лікування та реабілітацію у зв'язку з хворобами, травмами, отруєннями і патологічними станами, а також у зв'язку з вагітністю та пологами [1].

Зважаючи на зазначене, медична політика держави спрямована на поліпшення якості надання медичної допомоги своїм громадянам і розвивається у напрямі гармонізації та уніфікації із загальноприйнятими міжнародними нормами і стандартами. 3 цією метою в Україні створюються сприятливі умови для імплементації європейських підходів щодо розроблення медико-технологічних документів на основі найкращих клінічних настанов, адаптованих до умов вітчизняної системи охорони здоров'я, формується необхідна нормативно-правова база діяльності органів законодавчої та виконавчої влади, яка дає змогу контролювати якість надання медичної допомоги, підвищувати кваліфікацію медичних фахівців та розвивати наукову діяльність [2].

Проте оцінити стан стандартизації в системі охорони здоров'я України та діяльності закладів охорони здоров'я неможливо без короткого історичного екскурсу. Перші спроби опрацювання та впровадження системи стандартизації у медичній галузі зроблено наприкінці 80-х - початку 90-х років минулого століття, що було обумовлено як необхідністю 
підвищення якості надання медичної допомоги населенню, так і впровадженням в охорону здоров'я нового господарського механізму. Процес стандартизації на цьому етапі характеризувався розробкою клінікостатистичних груп і медико-економічних стандартів та імплементацією автоматизованої системи контролю якості, проте його розвиток уповільнився через недосконалість економічних механізмів і нерозвиненість ринкових відносин. Першою галузевою розробкою медичних стандартів у системі охорони здоров'я країни були «Тимчасові галузеві уніфіковані стандарти медичних технологій діагностичнолікувального процесу стаціонарної допомоги дорослому населенню в лікувальнопрофілактичних закладах України та Тимчасові стандарти обсягів діагностичних досліджень, лікувальних заходів та критеріїв якості лікування дітей» $[3,4,5]$.

У цей же час медичними фахівцями ряду лікувально-профілактичних закладів обласного рівня було розроблено та впроваджені у практичну діяльність деякі стандарти лікувально-діагностичного процесу і якості лікування хворих, при цьому використовувались моделі кінцевих результатів лікування, впроваджувались автоматизовані системи контролю якості тощо. Водночас проведений аналіз розроблених у медичних закладах стандартів медичних технологій розкрив як позитивні, так і негативні результати даного процесу: стандарти не мали єдиного наукового і методологічного обгрунтування, були відсутні єдині вимоги до об'єкту стандартизації та єдині критерії, атрибути, елементи стандарту. Для адекватного використання та подальшого аналізу існуючої нормативної бази постала необхідність пошуку та систематизації загального масиву документів, що регламентують клінічні аспекти надання медичної допомоги пацієнтам [4].

У 2008 році вперше проведено узагальнення стандартів надання медичної допомоги, клінічних протоколів, нормативів надання медичної допомоги, методичних рекомендацій та інших нормативних документів, які визначали порядок та обсяги діагностичних досліджень i лікування, та висвітлено на сайті Міністерства охорони здоров'я (M03) України та в інших джерелах інформації. Було сформовано «Базу стандартів медичної допомоги в Україні» у вигляді таблиці EXCEL, яка містила опис нормативних документів та посилання на файли зі змістом відповідних документів.
3 метою створення єдиної системи стандартизації в галузі охорони здоров'я, реалізації заходів 3 організації, координації процесу стандартизації медичної допомоги, інформаційного та фінансового забезпечення, удосконалення відповідної нормативноправової бази наказом М03 України від 25.06.2008 року № 341 було затверджено Галузеву програму стандартизації медичної допомоги на період до 2010 року, яка ставила за мету створення єдиної державної системи стандартизації в охороні здоров'я, реалізацію заходів 3 організації, координації процесу стандартизації медичної допомоги, ï інформаційне та фінансове забезпечення, удосконалення відповідної нормативноправової бази. Крім того, у програмі було визначено шляхи її реалізації, основні заходи, принципи та очікувані результати [6]. Незважаючи на те, що заходи зазначеної програми були виконані не в повному обсязі, з цього часу робота щодо стандартизації медичної допомоги набула в Україні системного характеру.

У 2011 році закон України «Основи законодавства України про охорону здоров'я» було доповнено статтею 14-1, яка визначає систему стандартів у сфері охорони здоров'я, порядок встановлення державних соціальних нормативів у сфері охорони здоров'я та перелік галузевих стандартів у сфері охорони здоров'я [7].

M03 України, як центральним органом виконавчої влади, що забезпечує формування та реалізацію державної політики у сфері охороні здоров’я, видано численну кількість наказів, що визначають подальший розвиток стандартизації в системі охорони здоров'я, порядок опрацювання стандартів надання медичної допомоги та клінічних протоколів, а також впровадження самих стандартів i протоколів [8, 9, 10, 11, 12, 13, 14, 15].

На цей час в системі здоров'я України розроблено та впроваджено численну кількість медико-технологічних документів 3 метою забезпечення надання якісної медичної допомоги населенню шляхом впровадження медичних стандартів на засадах доказової медицини відповідно до сучасних вимог провідних країн світу, що контролюють діяльність системи охорони здоров'я. Водночас ця робота не $€$ завершеною та постійно продовжується, що обумовлено динамічним розвитком медичної науки, появою новітнього медичного обладнання і сучасних лікарських 
засобів, розробленням та впровадженням нових методів діагностики і лікування тощо.

Процеси стандартизації на цей час $\epsilon$ актуальними також для Збройних Сил (3С) України під час їх трансформації та розвитку на шляху наближення до стандартів збройних сил держав-членів НАТО.

Мета роботи. Обгрунтування необхідності розроблення системи військовомедичних стандартів та визначення порядку їх впровадження у систему медичного забезпечення 3С України

Матеріали та методи. Використано законодавчі та нормативно-правові акти 3 питань охорони здоров'я, керівні документи щодо медичного забезпечення 3С України, інформаційно-довідкові матеріали, монографії та наукові статті у відкритих виданнях щодо опрацювання та провадження стандартів надання медичної допомоги в системі охорони здоров'я цивільного населення, а також керівні документи з медичного забезпечення збройних сил держав-членів НАТО. Методи дослідження: бібліографічний, аналітичний, системного підходу, узагальнення, прогностичний.

Результати та їх обговорення. Системне реформування у сфері національної безпеки та оборони в Україні висуває високі вимоги до медичного забезпечення ЗС України. Одним із ефективних механізмів впливу держави на якість надання медичної допомоги військовослужбовцям $\epsilon$ стандартизація медичного забезпечення, що спрямована на досягнення оптимального ступеня впорядкування в системі військової охорони здоров'я шляхом розроблення та впровадження норм, вимог, правил, технологій, робіт, послуг, що застосовуються в охороні здоров'я.

Відповідно до Указу Президента України «Про нову редакцію Воєнної доктрини України» одним із шляхів досягнення цілей воєнної політики України визначено модернізацію військової охорони здоров'я у напрямі концентрації зусиль на заходах з медичного забезпечення військ (сил) у можливих конфліктах 3 максимальною iї інтеграцією 3 цивільною системою охорони здоров'я [16].

Впровадження у діяльність військовомедичних служб сучасних технологій «надання медичної допомоги і лікування поранених відповідно стандартів медичної допомоги i лікування поранених відповідно до стандартів медичної допомоги, клінічних протоколів та інших галузевих стандартів у сфері охорони здоров'я» передбачалося також оперативною ціллю 4.2. Побудова системи медичного забезпечення для надання належної медичної підтримки всім завданням сил оборони Стратегічного оборонного бюлетеня України, що затверджений Указом Президента України від 06 червня 2016 року № 240/2016 [17].

Одним із пріоритетних завдань, визначених Воєнно-медичною доктриною України, $€$ «формування та впровадження єдиних підходів щодо збереження та зміцнення здоров'я військовослужбовців, організації і надання медичної допомоги їм у разі поранень, уражень і захворювань, якнайшвидшого відновлення боєздатності та працездатності шляхом застосування медичних стандартів НАТО та переходу на рівневу систему медичного забезпечення військ», а одним із її принципів визначено організацію «медичного забезпечення та надання медичної допомоги відповідно до стандартів медичної допомоги (медичних стандартів), клінічних протоколів та військово-медичних стандартів» [18].

у Доктрині медичного забезпечення Збройних Сил України одним із основних принципів медичного забезпечення визначено «проведення лікувально-профілактичних заходів відповідно до загальнодержавних медичних стандартів і клінічних протоколів та військово-медичних стандартів» [19].

Також слід зазначити, що особлива увага питанням стандартизації надання медичної допомоги військовослужбовцям та медичного забезпечення військ приділяється у збройних силах держав-членів НАТО, зокрема під час спільного виконання ними завдань, що знайшло своє відображення у Принципах і політиці медичного забезпечення НАТО (MC 0326/4) i Спільній доктрині з медичного забезпечення HATO (AJP-4.10 (C) [20, 21].

Таким чином, одним із напрямів реформування та розвитку військової охорони здоров'я в Україні $\epsilon$ створення єдиної уніфікованої системи стандартизації медичного забезпечення $3 \mathrm{C}$ України, максимально наближеної до стандартів системи цивільної охорони здоров'я, яка враховуватиме досвід медичного забезпечення військ збройних сил держав-членів НАТО.

На цей час М03 України розроблено та впроваджено чимало медико-технологічних документів 3 метою забезпечення надання якісної медичної допомоги населенню шляхом впровадження медичних стандартів на засадах доказової медицини відповідно до сучасних вимог провідних країн світу, що контролюють діяльність системи охорони здоров'я. Переважна більшість їх стосується клінічних 
аспектів надання медичної допомоги. Зазначені напрацювання MO3 України потребують адаптації до системи військової охорони здоров'я та впровадження в практичну діяльність Медичних сил шляхом розроблення та затвердження відповідних військовомедичних стандартів, а в подальшому організації контролю за їх дотриманням. Крім того, вкрай важливою для ЗС України $€$ стандартизація надання медичної допомоги в особливий період, зокрема на передових рівнях медичного забезпечення.

Проте у ЗС України на цей час розроблено військові стандарти лише 3 окремих питань організації медичного забезпечення військ та надання медичної допомоги пораненим, травмованим, ураженим i хворим військовослужбовцям, медичного постачання та матеріально-технічного забезпечення медичної служби, а також підготовки військово-медичних фахівців. Певну увагу питанням дослідження стандартизації надання медичної допомоги ЗС України було приділено свого часу на кафедрі організації медичного забезпечення збройних сил та деяких клінічних кафедрах Української військово-медичної

(УВMA) [22, 23, 24, 25, 26, 27].

Велику увагу необхідності стандартизації медичного забезпечення військ приділено у дисертаційному дослідженні Микити 0.0. «Наукове обгрунтування стандартизації медичного забезпечення Збройних Сил України в умовах антитерористичної операції». Мета дослідження полягала у науковому обгрунтуванні функціонально-організаційної моделі стандартизації елементів системи медичного забезпечення Збройних Сил України, розробленні та упровадженні пріоритетних військово-медичних стандартів в умовах антитерористичної операції [28].

Практичне значення

одержаних результатів наукової роботи полягало у тому, що вони стали підставою для розробки $\mathrm{i}$ впровадження: військових стандартів медичного забезпечення щодо підготовки військовослужбовців і санітарних інструкторів роти (батареї) з надання медичної допомоги в умовах збройних конфліктів та стандарту надання першої медичної допомоги військовослужбовцям при бойових травмах; пропозицій щодо створення навчальнотренувального центру для підготовки санітарних інструкторів підрозділів 3С України та розробки програми фахової підготовки санітарних інструкторів у навчальних військових центрах ЗС України; індивідуальних засобів медичного захисту (аптечки медичної загальновійськової індивідуальної (АМЗI)) i групових засобів медичного призначення (наплічника медичного санітарного інструктора роти (батареї)).

За результатами проведених досліджень винесено практичні рекомендації Міністерству оборони України щодо необхідності продовження дослідження організації стандартизації системи медичного забезпечення ЗС України та використання результатів дисертаційної роботи при проведенні науково-дослідних робіт з проблем організації медичного забезпечення населення та військ (сил), а органам управління медичним забезпеченням (Військово-медичному департаменту Міністерства оборони України та Центральному військово-медичному управлінню Збройних Сил України) - розробити нормативно-правові засади щодо організації розроблення військових стандартів медичного забезпечення ЗС України.

Українській військово-медичній академії рекомендовано створити тематичні групи із залученням відповідних кафедр для розробки військових стандартів медичного забезпечення 3С України з навчання та надання медичної (домедичної) допомоги, а також розглянути можливість внесення змін до організаційноштатної структури Науково-дослідного інституту УВМА та створити у ньому науковоорганізаційний відділ стандартизації медичного забезпечення 3С України для розробки військових стандартів медичного забезпечення 3С України 3 організації та медичного оснащення.

У 2017-2018 роках в УВМА було проведено науково-дослідну роботу «Обгрунтування стандартизації системи медичного забезпечення Збройних Сил України в ході застосування військ (сил)», шифр «Стандарт», результатом виконання якої стала розробка та затвердження ряду керівних документів 3 питань медичного забезпечення військ, опрацювання та видання навчальних i методичних посібників, керівництв, розроблення навчальних програм, серед яких:

- Стандартизація медичного забезпечення Збройних Сил України: методичні рекомендації / M.I. Бадюк, 0.О. Микита, Д.В. Ковида, С.М. Рудинська, І.К. Середа // К.: РВВ УВМА. 2015. - 20 c.;

- Стандарт підготовки I-CT-3: підготовка військовослужбовця 3 тактичної медицини (видання 2). - К.: «МП Леся». - 2016. - 148 с.;

- Стандарт підготовки: Фахова підготовка 
санітарного інструктора роти (батареї) (видання 1). - К.: «МП Леся». - 2016. - 416 с.;

- Керівництво 3 організації постачання медичною технікою та майном Збройних Сил України у мирний час (введено в дію наказом директора Військово-медичного департаменту Міністерства оборони України від 12.12.2016 р. № 36);

-наказ Міністерства оборони України від 11.05.2017 р. № 261 «Про затвердження Порядку постачання медичного майна Збройним Силам України в мирний час»;

-Екстрена медична

допомога військовослужбовцям на догоспітальному етапі в умовах збройних конфліктів: Навчальний посібник. / За редакцією професора Бадюка M.I. - К.: СПД. Чалчинська Н.В. - 2018. - 209 с.;

-Програма навчальної дисципліни підготовки фахівців другого (магістерського) рівня вищої освіти «Підготовка офіцерів запасу», модуль «Домедична допомога в екстремальних ситуаціях», затверджена директором Військовомедичного департаменту МО України та заступником Міністра охорони здоров'я України у червні 2017 року.

Крім того, на цей час опрацьовано та затверджено встановленим порядком ряд керівних документів 3 питань медичного забезпечення, які також можна віднести до військово-медичних стандартів, зокрема щодо норм постачання медичного майна на особливий період (накази начальника Генерального штабу - Головнокомандувача 3С України від 30.06.2015 № *2 та № *3), складу аптечок медичних загальновійськових індивідуальних, аптечки автомобільної загальновійськової, наплічника медичного загальновійськового санітара та санітарного інструктора (наказ МОЗ України від 25.01.2017 № 113/29981) та деякі інші.

\section{Висновки}

1. Законодавством України 3 питань охорони здоров'я передбачено впровадження системи стандартів у сфері охорони здоров'я шляхом встановлення державних соціальних нормативів та визначення переліку галузевих стандартів у сфері охорони здоров'я.

2. На цей час відбувається процес трансформації та розвитку ЗС України з метою досягнення ними оперативної i технічної сумісності зі збройними силами держав-членів НАТО шляхом розроблення та впровадження системи вітчизняних військових стандартів у відповідності до стандартів НАТО.

3. Дослідження наявних у ЗС України медико-технологічних документів, призначених
Проте до цього часу робота щодо стандартизації медичного забезпечення 3С України залишається незавершеною, а система військово-медичних стандартів не сформованою, що потребує проведення науково-дослідної роботи із зазначеної проблеми.

Свого часу у ЗС України наказом Генерального штабу Збройних Сил України ще у 2012 році було затверджено Систему оперативних стандартів Збройних Сил України (Систему документів 3 питань управління, застосування, підготовки та забезпечення), яка містила перелік та ієрархію доктринальних, керівних, методичних та інформаційнодовідкових документів [36]. Водночас у цьому документі система військово-медичних стандартів була відсутньою.

У 2021 році директивою Головнокомандувача Збройних Сил України «Про організацію розробки доктринальних документів Збройних Сил України» введено в дію «Ієрархію основоположних доктринальних документів (головна та ключові) Збройних Сил України», проте документи 3 медичного забезпечення 3С України в ній відсутні [37].

За таких обставин у відповідності до законодавства України $[1,38]$, а також нормативно-правових актів i керівних документів 3 питань охорони здоров'я військовослужбовців та медичного забезпечення ЗС України $€$ необхідність розроблення та затвердження системи військово-медичних стандартів. Ця система передбачатиме ієрархію військово-медичних стандартів, їх розподіл по групах (організаційні, клінічні, підготовки тощо), перелік стандартів у кожній групі, порядок їх затвердження, впровадження та використання.

для стандартизації надання медичної допомоги, засвідчило наявність проблем системного характеру, а саме - відсутність системи військово-медичних стандартів.

4. Створення системи стандартів у медичному забезпеченні $3 \mathrm{C}$ України, яка базується на передових науково-теоретичних розробках, дозволить гарантувати високу якість лікувально-профілактичних, санітарногігієнічних і протиепідемічних заходів, усіх складових процесу медичного забезпечення на основі адекватного рівня його організації, наявності сучасного технічного оснащення, всебічного ресурсного забезпечення та високого рівня підготовки медичних фахівців. 


\section{Перспективи подальших досліджень.} Вирішення означеної проблеми можливе шляхом виконання науково-дослідної роботи

\section{Література}

1. Закон України від 19.11.1992 № 2801-XII «Основи законодавства України про охорону здоров'я». Відомості Верховної Ради України (ВВР), 1993, № 4, ст. 19.

2. Шаркань М.П., Шаркань Я.П., Чемирисов В.В. Державна медична політика підвищення рівня якості медичної допомоги в Україні / Український журнал медицини, біології та спорту - № 1 (1). 2016. - С. 103-106.

3. Наказ Міністерства охорони здоров'я України від 27.07.1998 № 226 «Про затвердження Тимчасових галузевих уніфікованих стандартів медичних технологій діагностично-лікувального процесу стаціонарної допомоги дорослому населенню в лікувально-профілактичних закладах України та Тимчасових стандартів обсягів діагностичних досліджень, лікувальних заходів та критерії якості лікування дітей» (втратив чинність на підставі наказу МО3 України від 08.05.2014 № 310).

4. Бліхар В.Є., Морозов А.М., Шпак I.В., Хобзей М.К., Степаненко А.В., Ліщишина О.М., Островєрхова М.Н., Горох Є.Л., Шилкіна 0.О. Аналіз медико-технологічних документів зі стандартизації медичної допомоги та обгрунтування шляхів їх удосконалення // Вісник соціальної гігієни та організації охорони здоров'я України. - 2010. - № 4. - С. 72-80.

5. Сенюта I.Я. Стандарти у сфері охорони здоров'я як джерело правовідносин із надання медичної допомоги / [Електронний ресурс]. Режим доступу: https://medcom.unba.org.ua/publications/publicatio ns/print/2975-standarti-u-sferi-ohoroni-zdorov-yayak-dzherelo-pravovidnosin-iz-nadannya-medichnoidopomogi.html. Знято 04.09.2021.

6. Наказ Міністерства охорони здоров'я України від 25.06.2008 № 341 «Про затвердження Галузевої програми стандартизації медичної допомоги на період до 2010 року».

7. Закон України від 7.07.2011 № 3611-VI «Про внесення змін до Основ законодавства України про охорону здоров'я щодо удосконалення надання медичної допомоги». Відомості Верховної Ради України (ВВР), 2012, № 14, ст. 86.

8. Наказ Міністерства охорони здоров'я України від 16.09.2011 № 597 «Про затвердження Галузевої програми стандартизації медичної допомоги на період до 2020 року».

9. Наказ Міністерства охорони здоров'я України від 02.04 .2010 № 297 «Про затвердження стандартів та клінічних протоколів надання медичної допомоги зі спеціальності «Хірургія».

10. Наказ Міністерства охорони здоров'я України від 8.09.2012 № 751 «Про створення та впровадження медико-технологічних документів зі стандартизації медичної допомоги в системі Міністерства охорони здоров'я України». щодо розроблення системи військовомедичних стандартів у ЗС України.

Зареєстровано в Міністерстві юстиції України 29.11.2012 за № 2001/22313.

11. Наказ Міністерства охорони здоров'я України від 21.12.2012 № 1118 «Про затвердження та впровадження медико-технологічних документів зі стандартизації медичної допомоги при цукровому діабеті 2 типу».

12. Наказ Міністерства охорони здоров'я України від 01.06.2013 № 460 «Про затвердження протоколів медичної сестри (фельдшера, акушерки) з догляду за пацієнтом та виконання основних медичних процедур та маніпуляцій».

13. Наказ Міністерства охорони здоров'я України від 15.01.2014 № 34 «Про затвердження та впровадження медико-технологічних документів зі стандартизації екстреної медичної допомоги».

14. Наказ Міністерства охорони здоров'я України від 25.12.2014 № 1003 «Про затвердження та впровадження медико-технологічних документів зі стандартизації медичної допомоги при депресії».

15. Наказ Міністерства охорони здоров'я України від 04.11.2015 № 723 «Про затвердження та впровадження медико-технологічних документів зі стандартизації медичної допомоги при вірусному гепатиті C».

16. Указ Президента України від 24 вересня 2015 року № 555/2015 “Про рішення Ради національної безпеки і оборони України від 2 вересня 2015 року «Про нову редакцію Воєнної доктрини України».

17. Указ Президента України від 6 червня 2016 року № 555/2015 “Про рішення Ради національної безпеки і оборони України від 20 травня 2016 року «Про Стратегічний оборонний бюлетень України».

18. Постанова Кабінету Міністрів України від 31 жовтня 2018 року № 910 «Про затвердження Воєнно-медичної доктрини України».

19. Наказ Генерального штабу Збройних Сил України від 20.12.2017 № 445 «Про затвердження Доктрини медичного забезпечення Збройних Сил України.

20. Принципи i політика медичного забезпечення НАTO (MC 0326/4).

21. Спільна доктрина з медичного забезпечення HATO (AJP-4.10 (C).

22. Бадюк M.I. Методологія розробки стандартизованих документів надання медичної допомоги для військових закладів охорони здоров'я України / M.I. Бадюк, Б.Б. Жупан, В.П. Майданюк та ін. // Військова медицина України. - К., 2013. - № 3. - С. 5-6.

23. Бадюк M.I. Обгрунтування необхідності запровадження польової медичної картки пораненого у військовій охороні здоров'я України / М.I. Бадюк, О.О. Микита, А.М. Губар // Проблеми військової охорони здоров'я: зб. наук. пр. - К.: 
УВМА, 2015. - № 38. - С. 64-69. - Інв. № 724. Таємно.

24. Бадюк M.I. Проблеми упровадження системи якості медичної допомоги у закладах охорони здоров'я Міністерства оборони України / M.I. Бадюк, 0.0. Микита // Військова медицина України. - К., 2015. - № 1. - С. 5-10.

25. Бадюк M.I. Програма підготовки санітарних інструкторів у навчальних військових центрах Збройних Сил України / М.І. Бадюк, І.Ф. Гончаренко, В.П. Філіпішин [та ін.]. - К., 2015. - 57 с.

26. Аналіз якості домедичної допомоги пораненим в умовах антитерористичної операції після впровадження стандартів підготовки у Збройних силах України / М.I. Бадюк, 0.0. Микита, А.В. Швець та ін. // Екстрена медицина: від науки до практики. - К., 2015. - № 5-6 (16). - С. 79-89.

27. Бадюк M.I. Наукове обгрунтування моделі стандартизації медичного забезпечення Збройних Сил України та оцінка ї̈ ефективності / М.I. Бадюк, 0.0. Микита, А.М. Губар // Wschodnioeuropejskie Czasopismo Naukowe (East European Scientific Journal). - 2016. - № 7 - Р. 37-46.

28. Дисертація на здобуття наукового ступеня кандидата медичних наук Микити 0.0. «Наукове обгрунтування стандартизації медичного забезпечення Збройних Сил України в умовах антитерористичної операції». Спеціальність: 14.02.03 - Соціальна медицина. 2016.

29. Стандартизація медичного забезпечення Збройних Сил України: методичні рекомендації / М.І. Бадюк, О.О. Микита, Д.В. Ковида, С.М. Рудинська, І.К. Середа // К.: РВВ УВМА. - 2015. - 20 с.

30. Стандарт підготовки I-CT-3: підготовка військовослужбовця 3 тактичної медицини (видання 2). - К.: «МП Леся». - 2016. - 148 с.

\section{References}

1. Law of Ukraine of 19.11.1992 № 2801-XII "Fundamentals of the legislation of Ukraine on health care". Information of the Verkhovna Rada of Ukraine (VVR), 1993, № 4, Art. 19.

2. Sharkan, M.P., Sharkan, J.P., Chemirisov,V.V. (2016). State medical policy to improve the quality of medical care in Ukraine. Ukrainian Journal of Medicine, Biology and Sports. (1). 103-106.

3. Order of the Ministry of Health of Ukraine dated 27.07.1998 № 226 "On approval of the Provisional sectoral unified standards of medical technologies of diagnostic and treatment process of inpatient care for adults in medical institutions of Ukraine and the Provisional standards of diagnostic tests, treatment measures and quality criteria treatment of children "(repealed on the basis of the order of the Ministry of Health of Ukraine dated 08.05.2014 № 310).

4. Blikhar, V.E., Morozov, A.M., Shpak, I.V., Hobzey, M.K., Stepanenko, A.V., Lishchyshyna, O.M., Ostroverkhova, M.N., Gorokh, E.L., Shilkina, O.O. (2010). Analysis of medical and technological documents on standardization of medical care and substantiation of ways to improve them. Bulletin of social hygiene and health care organization of Ukraine. - № 4. - P. 72-80.
31. Стандарт підготовки: Фахова підготовка санітарного інструктора роти (батареї) (видання 1). - К.: «МП Леся». - 2016. - 416 с.

32. Керівництво 3 організації постачання медичною технікою та майном Збройних Сил України у мирний час (введено в дію наказом директора Військово-медичного департаменту Міністерства оборони України від 12.12.2016 р. № 36).

33. Наказ Міністерства оборони України від 11.05.2017 р. № 261 «Про затвердження Порядку постачання медичного майна Збройним Силам України в мирний час»

34. Екстрена медична допомога військовослужбовцям на догоспітальному етапі в умовах збройних конфліктів: Навчальний посібник. / За редакцією професора Бадюка M.I. - К.: СПД. Чалчинська Н.В. - 2018. - 209 с.

35. Програма навчальної дисципліни підготовки фахівців другого (магістерського) рівня вищої освіти «Підготовка офіцерів запасу», модуль «Домедична допомога в екстремальних ситуаціях», затверджена директором Військово-медичного департаменту МО України та заступником Міністра охорони здоров'я України у червні 2017 року.

36. Наказ Генерального штабу Збройних Сил України від 22.10.2012 № 220 «Про затвердження Системи оперативних стандартів Збройних Сил України (Системи документів з питань управління, застосування, підготовки та забезпечення)».

37. Директива Головнокомандувача Збройних Сил України від 04.06.2021 № Д-8 «Про організацію розробки доктринальних документів Збройних Сил України».

38. Закон України від 5 червня 2014 року № 1315-VII «Про стандартизацію». Відомості Верховної Ради (ВВР), 2014, № 31, ст. 1058.

5. Senyuta, I.Ya. Standards in the field of health care as a source of legal relations for the provision of medical care / [Electronic resource]. - Access mode: https://medcom.unba.org.ua/publications/publicatio ns/print/2975-standarti-u-sferi-ohoroni-zdorov-yayak-dzherelo-pravovidnosin-iz-nadannya-medichnoidopomogi. html. Taken on 04.09.2021.

6. Order of the Ministry of Health of Ukraine dated 25.06.2008 № 341 "On approval of the Sectoral program of standardization of medical care for the period up to 2010".

7. Law of Ukraine of 7.07.2011 № 3611-VI "On Amendments to the Fundamentals of the Legislation of Ukraine on Health Care to Improve the Provision of Medical Care". Information of the Verkhovna Rada of Ukraine (VVR), 2012, № 14, Art. 86.

8. Order of the Ministry of Health of Ukraine dated 16.09.2011 № 597 "On approval of the Sectoral program of standardization of medical care for the period up to 2020".

9. Order of the Ministry of Health of Ukraine dated 02.04.2010 № 297 "On approval of standards and clinical protocols for medical care in the specialty" Surgery ". 
10. Order of the Ministry of Health of Ukraine dated 8.09.2012 № 751 "On the creation and implementation of medical and technological documents for the standardization of medical care in the system of the Ministry of Health of Ukraine". Registered in the Ministry of Justice of Ukraine on November 29, 2012 under № 2001/22313.

11. Order of the Ministry of Health of Ukraine dated 21.12.2012 № 1118 "On approval and implementation of medical and technological documents for standardization of medical care for type 2 diabetes".

12. Order of the Ministry of Health of Ukraine dated 01.06.2013 № 460 "On approval of the protocols of the nurse (paramedic, midwife) for patient care and the implementation of basic medical procedures and manipulations."

13. Order of the Ministry of Health of Ukraine dated 15.01.2014 № 34 "On approval and implementation of medical and technological documents for standardization of emergency medical care".

14. Order of the Ministry of Health of Ukraine dated 25.12.2014 № 1003 "On approval and implementation of medical and technological documents for the standardization of medical care for depression."

15. Order of the Ministry of Health of Ukraine dated 04.11.2015 № 723 "On approval and implementation of medical and technological documents for standardization of medical care for viral hepatitis C".

16. Decree of the President of Ukraine of September 24, 2015 № 555/2015 “On the decision of the National Security and Defense Council of Ukraine of September 2,2015 " On the new version of the Military Doctrine of Ukraine".

17. Decree of the President of Ukraine of June 6, 2016 № 555/2015 “On the decision of the National Security and Defense Council of Ukraine of May 20, 2016" On the Strategic Defense Bulletin of Ukraine ".

18. Resolution of the Cabinet of Ministers of Ukraine of October 31, 2018 № 910 "On approval of the Military Medical Doctrine of Ukraine".

19. Order of the General Staff of the Armed Forces of Ukraine dated 20.12.2017 № 445 “On approval of the Doctrine of medical support of the Armed Forces of Ukraine.

20. NATO Principles and Policies (MS 0326/4).

21. NATO Common Medical Doctrine (AJP-4.10).

22. Badyuk, M.I., Zhupan, V.V., Maidanyuk, V.P. and others (2013). Methodology of development of standardized documents for providing medical care for military health care institutions of Ukraine. Military medicine of Ukraine. - № 3. P. 5-6.

23. Badyuk, M.I. Mikita, O.0., Gubar, A.M. (2015). Substantiation of the need to introduce a field medical card of the wounded in the military health care of Ukraine. Problems of military health care: collection. Science. papers. - K .: UMMA, № 38. 64-69. - Inv. № 724.

24. Badyuk, M.I. Mikita, 0.0. Problems of implementing the system of quality of medical care in health care institutions of the Ministry of Defense of Ukraine. Military Medicine of Ukraine. - K., 2015. - № 1. - P. 5-10.

25. Badyuk, M.I., Goncharenko, I.F., Filipishin, V.P. Program of training of sanitary instructors in educational military centers of the Armed Forces of Ukraine- K., 2015. - 57 p.

26. Badyuk, M.I. Mikita, O.O., Shvets, A.V and others. (2015)/ Analysis of the quality of home care for the wounded in an anti-terrorist operation after the introduction of training standards in the Armed Forces of Ukraine. Emergency medicine: from science to practice. № 5-6 (16). 79-89.

27. Badiuk, M. I., Mykyta, O. O., Hubar, A. M. (2016). Obgruntuvannia modeli standartyzatsii medychnoho zabezpechennia Zbroinykh Syl Ukrainy ta otsinka yii efektyvnosti. Wschodnioeuropejskie Czasopismo Naukowe (East European Scientific Journal), 7, 37-46..

28. The dissertation on competition of a scientific degree of the candidate of medical sciences Nikita 00 "Scientific substantiation of standardization of medical support of the Armed Forces of Ukraine in the conditions of anti-terrorist operation". Specialty: 14.02.03 - Social medicine. 2016

29. Badyuk, M.I., Mykyta, O.0., Kovyda, D.V., Rudyns'ka, S.M., Sereda, I.K. (2015). Standardization of medical support of the Armed Forces of Ukraine: methodical recommendations K :: RVV UVMA. 20 p.

30. Training standard I-ST-3: training of a serviceman in tactical medicine (edition 2). (2016). K. "MP Lesya". 148 p.

31. Training standard: Professional training of the sanitary instructor of the company (battery) (edition 1). (2016). K. "MP Lesya". 416 p.

32. Guidelines for the organization of supply of medical equipment and property of the Armed Forces of Ukraine in peacetime (put into effect by order of the Director of the Military Medical Department of the Ministry of Defense of Ukraine dated 12.12.2016 № 36).

33. Order of the Ministry of Defense of Ukraine dated 11.05.2017 № 261 "On approval of the Procedure for the supply of medical equipment to the Armed Forces of Ukraine in peacetime"

34. Emergency medical care for servicemen at the pre-hospital stage in armed conflicts: A textbook. (2018). Edited by Professor M.I. Badyuk - K .: Chalchynska NV - 209 p.

35. The program of training of specialists of the second (master's) level of higher education "Training of reserve officers", module "Domestic care in extreme situations", approved by the Director of the Military Medical Department of the Ministry of Defense of Ukraine and Deputy Minister of Health of Ukraine in June 2017.

36. Order of the General Staff of the Armed Forces of Ukraine dated 22.10.2012 № 220 "On approval of the System of operational standards of the Armed Forces of Ukraine (System of documents on management, application, training and support)".

37. Directive of the Commander-in-Chief of the Armed Forces of Ukraine dated 04.06.2021 № D-8 "On the organization of the development of doctrinal documents of the Armed Forces of Ukraine".

38. Law of Ukraine of June 5, 2014 № 1315-VII "On Standardization". Information of the Verkhovna Rada (VVR), 2014, № 31, Art. 1058 


\title{
О НЕОБХОДИМОСТИ РАЗРАБОТКИ И ВНЕДРЕНИЯ СИСТЕМЫ ВОЕННО-МЕДИЦИНСКИХ СТАНДАРТОВ В ВООРУЖЕННЫХ СИЛАХ УКРАИНЫ
}

\author{
В.Г. Ливинский ${ }^{1}$, В.А. Жаховский ${ }^{1}$, О.М. Иванько ${ }^{1}$, В.М. Ивчук ${ }^{1}$, А.М. Серебряков ${ }^{2}$ \\ 1 Украинская военно-медицинская академия, г. Киев, Украина \\ 2 Житомирский военный госпиталь, г. Житомир, Украина
}

\begin{abstract}
Цель работы - обоснование необходимости разработки системы военно-медицинских стандартов и определение порядка их внедрения в систему медицинского обеспечения Вооруженных Сил (ВC) Украины.

Материалы и методы. Использованы законодательные и нормативно-правовые акты по вопросам здравоохранения, руководящие документы по медицинскому обеспечению ВС Украины, информационно-справочные материалы, монографии и научные статьи по разработке и производству стандартов оказания медищинской помощи, а также руководящие документы по медицинскому обеспечению вооруженных сил государств-членов НАТО. Объект исследования - система медицинского обеспечения ВС Украины. Предмет исследования - система военно-медицинских стандартов в ВС Украины. Методы исследования: библиографический, аналитический, системного подхода, обобщения,
\end{abstract} прогностический.

Результаты. Изучены и проанализированы нормативно-правовые акты, определяющие организацию и порядок медицинского обеспечения ВС Украины, необходимость внедрения военномедицинских стандартов в деятельность медицинской службы, а также руководящие документы по медицинскому обеспечению вооруженных сил государств-членов НАТО. Проведено исследование состояния разработки и внедрения системы военно-медицинских стандартов в ВС Украины и установлено, что к этому времени работа по стандартизации медицинского обеспечения ВС Украины не приобрела системный характер, разработаны лишь отдельные документы по стандартизации оказания медицинской помощи, подготовки военнослужащих с тактической медицины и медицинского снабжения. В целом же система военно-медицинских стандартов в ВС Украины остается неразработанной и не внедренной.

Выводы. Работа по разработке и внедрению системы военно-медицинских стандартов в медицинском обеспечении ВС Украины остается незавершенной, а система военно-медицинских стандартов неразработанной, что вызывает необходимость проведения научно-исследовательской работы по данной проблеме.

Ключевые слова: медицинское обеспечение ВС Украины, стандарты оказания медицинской помощи, система военно-медицинских стандартов.

\section{THE NECESSITY OF DEVELOPING AND IMPLEMENTING THE SYSTEM OF MILITARY MEDICAL STANDARDS INTO THE ARMED FORCES OF UKRAINE}

\author{
V.G. Livinskiy ${ }^{1}$, V.O. Zhahovskiy' ${ }^{1}$, O.M. Ivanko¹,V. M. Ivchuk1 ${ }^{1}$, O.M Serebryakov ${ }^{2}$ \\ 1 Ukrainian military medical academy, Kyiv, Ukraine \\ 2 Zhytomyr military hospital, Zhytomyr, Ukraine
}

The purpose is substantiation of the need to develop a system of military medical standards and determine the procedure for their implementation in the system of medical support of the Armed Forces (AF) of Ukraine.

Materials and methods. Legislative and normative-legal acts on health care, guiding documents on medical support of the Armed Forces of Ukraine, information and reference materials, monographs and scientific articles on the development and implementation of standards of medical care, as well as guiding documents on medical support of the armed forces are applied-NATO members. The object of research is the system of medical support of the Armed Forces of Ukraine. The subject of research is the system of military medical standards in the Armed Forces of Ukraine. Research methods: bibliographic, analytical, systems approach, generalization, prognostic.

Results. The normative legal acts defining the organization and procedure of medical support of the Armed Forces of Ukraine, the need to introduce military medical standards in the activities of the medical service, as well as guiding documents on medical support of the armed forces of NATO member states were studied and analyzed. A study of the state of development and implementation of the system of military medical standards in the Armed Forces of Ukraine and found that so far the work on standardization of medical care of the Armed Forces of Ukraine has not become systematic, developed only some documents on standardization of medical care, training in tactical medicine and medical supplies. In general, the system of military medical standards in the Armed Forces of Ukraine remains undeveloped and unimplemented.

Conclusions. The work on the development and implementation of the system of military medical standards in the medical support of the Armed Forces of Ukraine remains unfinished, and the system of military medical standards is undeveloped, which necessitates research on this issue.

Key words: medical support of the Armed Forces of Ukraine, standards of medical care, system of military medical standards.

Конфлікт інтересів: відсутній.

Conflicts of interest: authors have no conflict of interest to declare. 
Відомості про авторів:

Лівінський В.Г. А,B,C,D,E.F - к.мед.н., провідний науковий співробітник Науково-дослідного інституту проблем військової медицини Української військово-медичної академії, м. Київ.

Жаховський В.О. А,В,C,D,E,F - к.н.держ.упр., доц., провідний науковий співробітник Науководослідного інституту проблем військової медицини Української військово-медичної академії, м. Київ.

Іванько О.М. В,С - підполковник медичної служби, д.мед.н., доцент, начальник Науково-дослідного інституту проблем військової медицини Української військово-медичної академії, м. Київ.

Івчук В.М. в,С - полковник медичної служби, начальник науково-дослідного відділу Науководослідного інституту проблем військової медицини Української військово-медичної академії, м. Київ.

Серебряков О.М. Е - полковник медичної служби, к.мед.н., начальник Житомирського військового госпіталю, м. Житомир.

$A$ - концепція та дизайн дослідження; $B$ - збір даних; $C$ - аналіз та інтерпретація даних;

$D$ - написання статmi; $E$ - редагування статmi; F- остаточне затвердження статті.

\section{Сведения об авторах:}

Ливинский В.Г. - к.мед.н., ведущий научный сотрудник Научно-исследовательского института проблем военной медицины Украинской военно-медицинской академии, г. Киев, Украина.

Жаховский В.А. - к.н.гос.упр., доц., ведущий научный сотрудник Научно-исследовательского института проблем военной медицины Украинской военно-медицинской академии, г. Киев, Украина.

Иванько о.М. - подполковник медицинской службы, д.мед.н., доц., начальник Научноисследовательского института проблем военной медицины Украинской военно-медицинской академии, г. Киев, Украина.

Ивчук В.М - полковник медицинской службы, начальник научно-исследовательского отдела Научно-исследовательского института проблем военной медицины Украинской военно-медицинской академии, г. Киев, Украина.

Серебряков А.М. - полковник медицинской службы, к.мед.н., начальник Житомирского военного госпиталя., г. Житомир, Украина.

\section{Information about authors:}

Livinskyi V.G. A,B,C,D,E,F - PHD med, Research Institute of Military Medicine of the Ukrainian Military Medical Academy, leading researcher of the research department of medical standardization and metrological support. Email: v.livinskiy@gmail.com, https://orcid.org/0000-0002-1102-1128, Kyiv.

Zhakhovsky V.O. A,B,C,D,E,F - candidate of science in public administration, associate professor, Research Institute of Military Medicine of the Ukrainian Military Medical Academy, leading researcher of research department of medical support organization. Email: zhahovskiy-viktor@ukr.net, https://orcid.org/0000-00022665-2766, Kyiv.

Ivanko O.M. ${ }^{\mathrm{B}, \mathrm{C}}$ - Lt Col MS, MD, associate professor, Head of the Research Institute of Military Medicine of the Ukrainian Military Medical Academy, Kyiv.

Ivchuk V.M. B,C - Col MS, Head of the Research Department of the Research Institute of Military Medicine of the Ukrainian Military Medical Academy, Kyiv.

Serebryakov O.M. E - Col MS, MD Phd, Head of the Zhytomyr Military Hospital, Zhytomyr.

$A$ - research concept and design; $B$ - collection and/or assembly of data; $C$-data analysis and interpretation; $D$ - writing the article; $E$ - critical revision of the article; $F$ - final approval of the article.

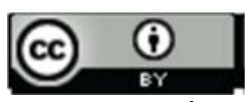

Адреса для листування: вул. Московська, 45/1, буд. 33, м. Київ 01015. 